\title{
Evaluation of Different Materials Used for Fabrication of Complete Digital Denture
}

\begin{abstract}
CLAUDIA FLORINA ANDREESCU1', DOINA LUCIA GHERGIC1', OANA BOTOACA', VIOLETA HANCU'*, ANDREEA MARIANA BANATEANU ${ }^{1}$, DAN NICOLAE PATROI ${ }^{1}$

${ }^{1}$ Titu Maiorescu University of Bucharest, Faculty of Dentistry, Department of Dental Specialities, 67A Gheorghe Petrascu Str., Bucharest, Romania

Utilization of computer-aided design/computer-aided manufacturing (CAD/CAM) rapidlyincreases in dental medicine. Making of computer-engineered complete denture is based on scanning of patient data, designing of prosthesis and milling or rapid prototyping. This is digital denture, term that includes innovative devices, software programmes and corresponding materials. Industrially polymerized cross-linked polymethyl methacrylate (PMMA) is the material used for fabrication of digital denture. The aim of this study is to analyze the different cross-linked PMMA used for fabrication of CAD/CAM complete denture.
\end{abstract}

Keywords: polymethyl methacrylate, CAD/CAM technology, complete denture

Utilization of computer-aided design/computer-aided manufacturing (CAD/CAM) increases in dental medicine since mid-1980 when it was introduced [1]. It has started with single-unit restorations (inlays, onlays, crowns) and now is extended to multi-unit restorations (bridges, implant-supported prosthesis and dentures). Making of computer-engineered complete denture is based on scanning of patientdata, designing of prosthesis and milling or rapid prototyping (fig. 1). This is digital denture, term that includes innovative devices, software programmes and corresponding materials. The CAD/CAM manufacturing process reduces the chair time, by reducing the number of appointments. Commonly, computer-engineered complete dentures need two clinical appointments. The first appointment involves clinical data collection (clinical records) and second appointment involved placement of computer-engineered complete denture. Optional, a third appointment can be included for a trial placement.

Fabrication of complete denture with the help of CAD/ CAM technology is related with apparition of high-density polymers based on highly cross-linked polymethylmethacrylate (PMMA) [2].

PMMA is the most popular material used for fabrication of partial or complete denture, due to its advantages: good esthetic characteristic, low water absorption and solubility, adequate strength, low toxicity, easy repair and simple processing technique [3]. Disadvantages include: porosity, presence of residual monomer which is a potential allergen, increased finishing time, brittle and uneven thickness [4]. Reinforcements with different materials were made in attempt to improve the mechanical properties [5-7], but allergy and citotoxicity of PMMA was frequently debate, especially in case of complete denture wearers $[8,9]$.
PMMA is a thermoplastic, transparent, environmental stable plastic, with chemical formula $\left(\mathrm{C}_{5} \mathrm{O}_{2} \mathrm{H}_{0}\right) \mathrm{n}$. It is a strong, but lightweight polymer with a density of 1.17-1.20 $\mathrm{g} / \mathrm{cm}^{3}$ [10] possessing a compressive strength between 85 and $110 \mathrm{MPa}$ and a tensile strength between 30 and 50 MPa [11]. PMMA possesses a relatively high coefficient of thermal expansion, and during polymerization in situ, temperatures can reach high values as 40 and $56^{\circ} \mathrm{C}$ [12]. Consequently, during curing process in vivo can result in a shrinkage of around 6-7\% [13] and cause a lack of optimal feet and tissue irritation. PMMA has a maximum water absorption ratio of $0.3-0.4 \%$ by weight [14], and this modifies tensile strength, which decreases with water absorption [15].

PMMA is the synthetic polymer of methyl-methacrylate (MMA) (fig. 2). The process of obtaining is called polymerization and is the formation of very large molecule bythe connection of many small, linkable, molecules called monomers. The double bond in MMA monomers allow them to bond to one-another when the appropriate conditions are present. The polymerization reaction is generated by production of free radicals, like benzoyl peroxide and itis induced by: heat (heat-curing), chemical (auto-curing) curing or light (light-curing). These initiate the polymerization process and MMA monomer, will begin the polymerization process by linking repeatedly, increasing its molecular weightmany thousand fold. During this process not all the monomer molecules are converted and consequently, some monomer molecules remain unpolymerized [16].

The disadvantages of PMMA are related with the presence of this unreacted monomer (MMA). This residual monomer is responsible for toxicity $[17,18]$, low
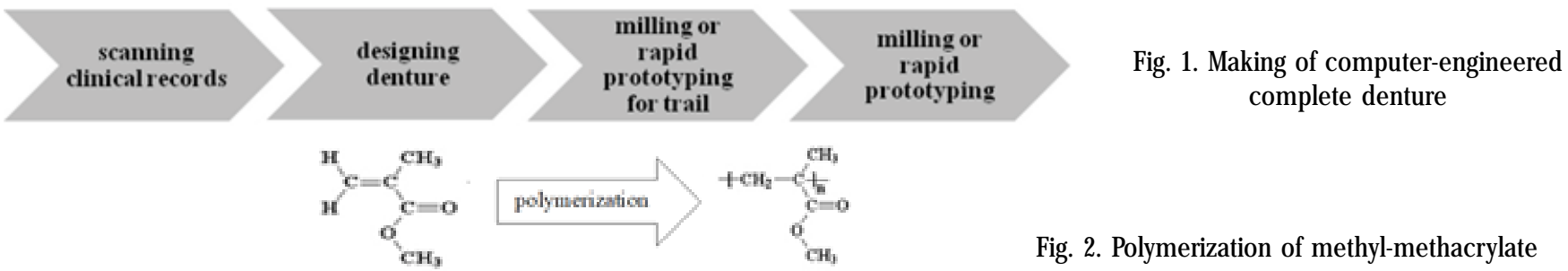

Fig. 2. Polymerization of methyl-methacrylate 
mechanical properties of PMMA [19] and water absorption $[20,21]$. MMA is associated with immune hypersensitivity reactions in the gingiva and mucosa, MMA molecules are small and hydrophilic and diffuses fast into oral cavity and body [22].

The polymerization temperature and time considerably influenced the quantity of residual monomer content $[23,24]$. Heated activated PMMA has high molecular weight, less porosity, better strength, lower residual monomer contentand less distortion and initial deformation when compared with chemically (auto) activated PMMA $[25,26]$.

PMMA can de synthetized as simple linear chainstructure or cross-linked (complex three-dimensional network). Cross-linking is a method in which polymer structure is modified by the process of interlinking the polymer chains through ionic or covalent bonds. This process is carried out by using chemical cross-linking or physical procedures with the purpose to improve physical and chemical properties of new cross-linked polymer. In case of PMMA, cross-linking increases rigidity, craze resistance and creep [22]. Craze resistance is the tendency of resins to form minute surface cracks and creep is resistance to deformation of denture base under load due to viscoelastic properties.

The aim of this study is to analyze the different crosslinked PMMA used for fabrication of CAD/CAM complete denture.

\section{Experimental part}

Presentation of available cross-linked PMMA polymers used for fabrication of digital complete denture

At present, there are more systems are available for production of CAD/CAM dentures: AvaDent ${ }^{\mathrm{TM}}$ (Global Dental Science), Baltic Denture System ${ }^{\mathrm{TM}}$ (Merz Dental GmbH), Ceramill Full Denture System (Amann Girrbach AG), DENTCA/Whole You ${ }^{\text {TM }}$ (DENTCA, Inc; Whole You, Inc), and Wieland Digital Denture ${ }^{\mathrm{TM}}$ (Ivoclar Vivadent, Inc), which provide CAD/CAM fabrication of complete dentures. These systems provide tools for registration of patient data, scanner, software, milling device and materials for digital denture fabrication.

This study focusses on polymeric material properties for digital denture base (table 1).

ISO standard for polymeric denture base 20795-1:2013 [27] requests the following specification for acrylic polymers:

-no voids that can be observed by visual inspection,

-ultimate flexural strength shall be not less than $65 \mathrm{MPa}$; -flexural modulus shall be at least $200 \mathrm{MPa}$,

-the upper limit for MMA residual monomer is $2.2 \%$ mass fraction,

-water sorption must not exceed $32 \mu \mathrm{g} / \mathrm{mm}^{3}$,

-solubility in water must not exceed $1.6 \mu \mathrm{g} / \mathrm{mm}^{3}$.

AvaDent $^{\mathrm{T}}$ digital dentures are precision-milled from a patented bio-hygienic puck of acrylic and milled or bonded teeth processes can be selected. The base is AvaDent ${ }^{\mathrm{TM}}$ puck, a specially crafted acrylic puck, extreme crosslinked, produced industrially under much higher pressure than that used in a traditional injection process. AvaDent ${ }^{T M}$ provides three types of milled dentures [28]:

$-X C L-2$, a monolithic denture (the teeth and the base are a single unit) that is fully-milled (base and dentition) from an individually made AvaDent ${ }^{T M}$ puck with polychromatic milled teeth;

-XCL-1, a monolithic denture that is fully-milled (base and dentition) from an individually made AvaDent ${ }^{\mathrm{TM}}$ puck with monochromatic milled teeth;

-milled base denture with bonded teeth from different tooth mould manufacturers (Candulor AG, Ivoclar Vivadent $A G$, Dentsply International Inc).
The AvaDent PMMA ${ }^{\mathrm{TM}}$ puck is compatible with Wieland, Sirona, Zirkonzahn, Datron and Roland milling machines [29].

\section{Results and discussions}

The following parameters were analyzed in comparison with conventional denture: flexural strength, reproduction of details, bacterial adhesion and concentration of residual monomer.

The flexural strength of the pre-polymerized CAD/CAM milled acrylic resin group was higher than that of conventional method groups of compression molded and injection molded [30].

The CAD-CAM fabrication process of complete denture was the most accurate and reproducible denture fabrication technique when compared with pack and press, pour, and injection denture base processing techniques [31].

The AvaDent ${ }^{\text {TM }}$ processed material is more hydrophobic than the conventional processed material what will result in a more bio-hygienic denture and did not increase the bacterial adhesion significantly when compared to conventional processing of complete denture and exhibit $20 \%$ lower concentration of residual monomer [32].

Baltic Denture System ${ }^{\mathrm{TM}}$ permit quick and easy fabrication of full dentures with different tooth libraries from different tooth manufacturers (VITA, Merz Dental and Heraeus Kulzer) with base made from a highly cross-linked, industrially polymerized, monomer-free PMMA blank [33], named BDLoad. It is a milling blank with integrated, functional dental set-up based on PMMA. The teeth are made of the prefabricated Polystar ${ }^{\circledR}$ also a highly crosslinked PMMA with organic modified polymer-network [34].

Compared to conventionally manufactured dentures, the material properties in terms of volume stability, tensile strength and a reduced monomer content of less than 1\% are significantly improved as a result of the controlled polymerization during industrial production of the ${ }^{\mathrm{BD}} \mathrm{Load}$ and the additional tempering process. The ${ }^{\mathrm{BD}}$ Load residual monomer content is under $1 \%$, flexural strength is more than $90 \mathrm{MPa}$ and water sorption is than $\mu \mathrm{g} / \mathrm{mm}^{3}$ [33].

Ceramill (Full Denture System) describes a completely continuous workflow for fabricating full dentures on a wax base, which can be adjusted, if necessary, after try-in by the dentist [35]. How ever, the milling machine from Amann Girrbach AG, Ceramill Motion 2 compatible with VITA VIONIC ${ }^{\circledR}$ BASE (VITA Zahnfabrik) is highly cross-linked, industrially polymerized, monomer-free PMMA blank [36].

DENTCA Whole You ${ }^{\text {T }}$, provide 3D printing dentures made of a type of acrylic similar to PMMA which has the same properties as conventional acrylic with the convenience of curing through UV (ultraviolet) light instead of temperature. The material fulfills International Standards ISO 10993-1 and ISO 20795-1 [37]. The denture base is then made layer by layer in a stereolithographic laser printer, each of which is light-cured before adding the next layer, with postcuring added in a light chamber. After that denture base is fitted with preformed plastic teeth and cured in a light chamber [38].

Ivoclar digital denture is a complete manufacturing process for the rapid production of removable full-arch dentures. IvoBase CAD is the denture base material, an impact-resistantPMMA disc, industrially manufactured that ensures a homogeneous material quality, without porosities or air bubbles in the material. This enhances the fracture resistance and increases the longevity of the denture for the patient. As a result of its homogeneity, denture bases made of these discs proved a significant difference in the adhesion of Candida albicans to the complete denture bases when compared with the conventional denture [39]. 


\begin{tabular}{|c|c|c|c|c|c|}
\hline & $\begin{array}{c}\text { AvaDent }^{\mathrm{TM}} \\
\text { (Global Dental } \\
\text { Science) }\end{array}$ & $\begin{array}{l}{ }^{\mathrm{BD}} \text { Load (Merz } \\
\text { Dental GmbH) }\end{array}$ & $\begin{array}{l}\text { VITA VIONIC }^{\otimes} \\
\text { BASE (VITA } \\
\text { Zahnfabrik) }\end{array}$ & $\begin{array}{l}\text { IvoBase CAD } \\
\text { (Ivoclar } \\
\text { Vivadent, Inc) }\end{array}$ & \multirow{11}{*}{$\begin{array}{c}\text { Table } 1 \\
\text { OVERVIEW OVER } \\
\text { PRODUCTION } \\
\text { SECIFICATIONS OF } \\
\text { DIFFERENT CAD / } \\
\text { CAM DENTURE } \\
\text { SYSTEMS }\end{array}$} \\
\hline Resin base & $\begin{array}{l}\text { Extreme cross- } \\
\text { linked PMMA }\end{array}$ & PMMA & PMMA & $\begin{array}{l}\text { High impact } \\
\text { PMMA }\end{array}$ & \\
\hline $\begin{array}{l}\text { Polymerization } \\
\text { record }\end{array}$ & $\begin{array}{l}\text { Under higher } \\
\text { pressure and } \\
\text { additional } \\
\text { tempering process }\end{array}$ & $\begin{array}{l}\text { Industrial and } \\
\text { additional } \\
\text { tempering process }\end{array}$ & $\begin{array}{l}\text { Pressure }>200 \mathrm{kN} \text {, } \\
\text { heat [50] }\end{array}$ & Industrial & \\
\hline Milling technique & $\begin{array}{l}\text { Five-axe milling } \\
\text { machine }\end{array}$ & $\begin{array}{l}\text { Five-axe milling } \\
\text { machine }\end{array}$ & Variable & $\begin{array}{l}\text { Five-axe milling } \\
\text { machine }\end{array}$ & \\
\hline Milling blank & $\begin{array}{l}\text { PMMA puck with } \\
\text { polymerization- } \\
\text { incorporated teeth } \\
\text { or PMMA puck } \\
\text { without teeth }\end{array}$ & $\begin{array}{l}\text { PMMA puck with } \\
\text { polymerization- } \\
\text { incorporated teeth }\end{array}$ & $\begin{array}{l}\text { PMMA puck } \\
\text { without teeth }\end{array}$ & $\begin{array}{l}\text { PMMA puck } \\
\text { without teeth }\end{array}$ & \\
\hline $\begin{array}{l}\text { Fixation of denture } \\
\text { teeth to denture } \\
\text { base }\end{array}$ & $\begin{array}{l}\text { Polymerization- } \\
\text { related } \\
\text { incorporation or } \\
\text { bonded }\end{array}$ & $\begin{array}{l}\text { Polymerization- } \\
\text { related } \\
\text { incorporation }\end{array}$ & $\begin{array}{l}\text { Methacrylate- } \\
\text { based bonding }\end{array}$ & $\begin{array}{l}\text { Methacrylate- } \\
\text { based bonding }\end{array}$ & \\
\hline Flexural strength & $145.61 \mathrm{MPa}[30]$ & $>90 \mathrm{MPa}[33]$ & Data not available & $\geq 65 \mathrm{MPa}[40]$ & \\
\hline Flexural modulus & Data not available & Data not available & Data not available & $\geq 2000 \mathrm{MPa}[40]$ & \\
\hline $\begin{array}{l}\text { MMA residual } \\
\text { monomer }\end{array}$ & $\begin{array}{l}<2.2 \% \text { mass } \\
\text { fraction [32] }\end{array}$ & $<1 \%[33]$ & $\begin{array}{l}\text { significantly less } \\
\text { monomer [50] }\end{array}$ & $\begin{array}{l}\leq 4.5 \% \mu \mathrm{g} / \mathrm{mm} \\
{[40]}\end{array}$ & \\
\hline Water sorption & Low & $<32 \mu \mathrm{g} / \mathrm{mm}^{3}[33]$ & Data not available & $\leq 32 \mu \mathrm{g} / \mathrm{mm}[40]$ & \\
\hline Solubility in water & Data not available & Data not available & Data not available & $\leq 1.6 \mu \mathrm{g} / \mathrm{mm} 3[40]$ & \\
\hline
\end{tabular}

Teeth are made of Vivodent CAD, tooth-colored discs milled from cross-linked material, which are suitable for the individual tooth design and production of whole tooth segment. Also teeth setfrom Candulor AG, Ivoclar Vivadent $A G$ can be used. Teeth are bonded to milled sockets into denture base with IvoBase Bond.

IvoBase CAD has the following characteristics: flexural strength $\geq 65 \mathrm{MPa}$, flexural modulus $\geq 2000 \mathrm{MPa}$, fracture toughness $\mathrm{Kmax} \geq 1.9 \mathrm{MPam} 1 / 2$, overall work of fracture $W f \geq 900 \mathrm{~J} / \mathrm{m}^{2}$, remaining quantity MMA $\leq 4.5 \%$, water absorption $\leq 32 \mu \mathrm{g} / \mathrm{mm}$ and water solubility $\leq 1.6 \mu \mathrm{g} /$ $\mathrm{mm} 3[40]$.

Numerous CAD/CAM systems for complete denture appear in the market, the majority of dentures is milled from pre-polymerized PMMA. There are systems, like
DENTCA/W hole You that use 3D printing for fabrication of denture base, but in this case material is similar with conventional PMMA. Computer-engineered complete dentures have several advantages over conventionally fabricated complete dentures.

Conventional denture fabrication presents sources of errors due to volumetric shrinkage of impression, volumetric expansion of casts, cast mounting errors and acrylic resin denture base shrinkage.

CAD/CAM fabrication of complete denture is based on laser scanning to digitize the final impressions and subtractive manufacturing to mill the denture bases using pre-polymerized PMMA cylinder. This block named puck or disc is produced under high pressure and heat to generate a cross-linked polymer. In CAD/CAM fabrication of 
complete denture volumetric shrinkage of impression cannot be excluded as source of errors.

The CAD/CAM denture base is milled from PMMA pucks that have been polymerized under high temperature and pressure [41]. In this way is promoted the formation of longer polymer chains [42] and therefore leads to a higher degree of monomer conversion with lower values of residual monomer.

The advantage of used of already polymerized PMMA is that polymerization shrinkage has already taken place and therefore the accuracy of the denture can be expected to be improved.

Polymerization regimen is confidential, it is specified just high-pressure. It is well-known that high-pressure polymerization lead to synthesis of high-molecular-weight polymers with well-defined structures with improved fracture resistance [42]. The effect of pressure has been reported to result in higher polymerization rates and in polymers with higher molecular weights and lower polydispersity [43-45].

Milled dentures are monolithic, base and teeth in one unit, or teeth, which could also milled, are chemically bonded to milled denture base.

Monolithic denture has the advantages of increases strength and reduces fracturing, reduces denture breakage and completely eliminates tooth delamination or loosing. In conventional denture bonding artificial teeth to denture base could lead to teeth detachment due to bond failure [46].

The milled teeth have a better resistance to wear in in vitro study when compare to conventional teeth [47].

A recent study [48] showed that in digitally fabricated dentures, the manual placing of the teeth into the denture base sockets can lead to deviations from the planned arrangement and this is an argument in favor of monolithic denture (base and teeth).

Many disadvantages of conventional PMMA are related to presence of residual monomer. Since milled dentures are produced from industrially polymerized PMMA disc, the producers claim that ingredients like MMA and initiators of polymerization are no longer present in denture. However residual monomer is inevitable for all PMMA-based products no matter what the curing conditions are, but extended time at high temperature can allow low values to be attained [49].

Steinmassl et al [50] investigated the monomer release after 7 days of water storage of four different CAD/CAM systems (Baltic Denture System, Vita VIONIC, Wieland Digital Dentures, Whole You Nexteeth). Conventional, heatpolymerized dentures served as control group. None of the $C A D / C A M$ dentures released significantly less monomer than the control group. There was no statistically significant association between the denture volume or denture weight and the cumulative monomer release. The range of monomer release was smallest among Baltic Denture System dentures, which are monolithic. In most CAD/CAM systems, the milling process produces denture bases with customized sockets for the insertion of the denture teeth that are then manually fixed into the sockets by using MMA bonding agents. This argument is supported by another study [51], which compares specimens of heat-cured PMMA and CAD/CAM pre-polymerized acrylic resin blocks and found a statistically significant difference in residual monomer content in favor of CAD/CAM pre-polymerized PMMA.

Another important parameter of PMMA denture base is the water uptake since it can cause swelling of the denture and change its mechanical properties. Wiedemair et al [52] presented data regarding the water uptake of CAD/ CAM denture base of two different companies. The water uptake was between 52.81 and $92.45 \mathrm{mg}$ of water over the course of one week for one company and between 141.11 and $206.43 \mathrm{mg}$ for the other company. The weight gain decreased steadily over the week and was only at about $7 \mathrm{mg}$ between the sixth and the seventh day, indicating that the dentures were almost saturated with water.

Milling device and type of milling is important to obtain a high quality denture. Milling devices are classified according to the number of milling axes: 3-axis, 4-axis and 5-axis milling devices. The 5-axis milling machines enable the milling of complex geometries with subsections, are fast and expensive.

Milling under water cooling (wet milling) is recommended for plastics since it prevents smearing and distortion, ensuring optimum fit of the denture and teeth in the tooth sockets. In addition, a smooth and ready for shine surface is obtained. A recent study [53] inspects the effects of mechanical polishing and chemical polishing on the surface roughness of heat-cured, auto-cured and CAD/CAM denture base acrylic resins. There is a statistical significant difference between them, in favor of CAD/CAM denture base; mechanical polishing produced lower surface roughness of CADICAM denture base resin with superior smooth surface compared to chemical polishing.

A smooth surface means a decrease in porosity and this decrease in porosity might diminish the adhesion of Candida to the dentures [54].

\section{Conclusions}

The available CAD/CAM denture fabrication systems provide a variety of advantages: reduced chair time and an improved quality of prosthetic device due to better fracture resistance and smoother surface. Monolithic dentures, teeth and base in one unit, have improved properties when compare with milled denture with bonded teeth. Quality of final denture depends also of type of milling machine and type of milling

Furthermore, the CAD/CAM process permits archivability, providing digital records for future replacement needs.

\section{References}

1.CALAMIA JR. Advances in computer-aided design and computeraided manufacture technology. Curr Opin Cosmet Dent. 1994:67-73. 2.ANDREESCU, C.F., GHERGIC, D.L, BOTOACA, O., BARBU, H.M., CERNUSCA MITARIU, I.S., PATROI DN. The Advantages of High-density Polymer CAD/CAM Interim Restorations in Oral Implantology. Mat. Plast., 54, no. 1, 2017, p. 32

3.URECHESCU, H., PRICOP, M., PRICOP, C., MATEAS ,M., NATANAEL, S., GALATANU, S.V., Thermoplastic Materials Used for Fabrication of Maxillary Obturator Prostheses. Mat. Plast. 54, no. 3, 2017, p. 477

4.BECHIR, A., PACURAR, M., BECHIR, E.S, COMANEANU MR, CIRES MC, MARIS M, BARBU H. Aesthetic Importance of Resin based Dental Materials used for Orthodontic Appliances. Mat. Plast.,51, no.1, 2014, p. 57

5.EARAR, K., MATEI, M.N, SANDU, A.V., HRISTIAN, L, BEJ INARIU, C, SANDU IG. The Role of Functional Polymers in the Optimisation of Acrylic Biomaterials used in Amovable Prosthetic Restoration I. The experimental protocol using the losipescu test, Mat. Plast., 52, no. 1,2015, p. 98

6.EARAR, K., BICA, C., CERGHIZAN, D., ILE, M., The Role of Functional Polymers in the Optimization of the Acrylic Biomaterials Used in Removable Prosthetic Restoration. III. Behaviour of the adhesive used for the multilayer consolidation. Mat. Plast., 53, no. 3, 2016, p. 512

7.TOTU, E.E., CRISTACHE, C.M., Could the Old Poly (methylmethacrylate) Face Arrising Challanges of New Advanced Technologies for Dental Prosthesis Manufacturing? Rev. Chim. (Bucharest), 68, no. 9, 2017, p. 2102 
8.RUSU, L.C, URECHESCU, H., ARDELEAN, L., LEVAI, M.C., PRICOP, M., Comparative Study for Oral Reaction Produced by Polymethylmethacrylate, Mat. Plast., 52, no. 3, 2015, p. 413

9.ANTOHE, M.E., DASCALU, C., SAVIN, C., FORNA, N.C., BALAN, A., Study Regarding the Toxic Effects of Acrylic Resins. Mat. Plast., 53, no. 4, 2016, p. 767

10.***Polymethylmethacrylate (PMMA, Acrylic) https://www. makeitfrom.com/material-properties/Polymethylmethacrylate-PMMAAcrylic.

11.J AEBLON T. Polymethylmethacrylate: properties and contemporary uses in orthopaedics. J Am Acad Orthop Surg 2010;18(5):297-305.

12.WEBB JC, SPENCER RF. The role of polymethylmethacrylate bone cement in modern orthopaedic surgery. J Bone Joint Surg $\mathrm{Br}$ 2007;89(7):851-7.

13.KUEHN KD, EGE W, GOPP U. Acrylic bone cements: composition and properties. Orthop Clin North Am 2005;36(1):17-28.

14.***DATA TABLE FOR: Polymers: Commodity Polymers: PMMA. https://www.matbase.com/material-categories/natural-and-syntheticpolymers/thermoplastics/commodity-polymers/material-propertiesof-polymethyl-methacrylate-extruded-acrylic-pmma.html\#properties. 15.ISHIYAMA C, YAMAMOTO Y, HIGO Y. Effects of Humidity History on the Tensile Deformation Behaviour of Poly (methyl-methacrylate) (PMMA) Films. MRS Online Proceedings Library Archive 2005;875. 16.MCCABE JF, WALLS A. Applied Dental Materials 9th ed. WilleyBlackwell Oxford, UK. 2013;p:112-113.

17.IOSIF L, AMZA OE, PREOTEASA E, AMZA G, PREOTEASA CT, DUMITRASCU C. Contributions Regarding the Assesment of Polymeric Materials used in complete Dentures by Thermographic analysis, Mat. Plast., 48, no. 1, 2011, p. 104

18.SINGH RD, GAUTAM R, SIDDHARTHA R, SINGH BP, CHAND P, SHARMA VP, JUREL SK. High performance liquid chromatographic determination of residual monomer released from heat-cured acrylic resin. An in vivo study. J Prosthodont 2013;22:358-61.

19.ROSU, S., Tissue Tolerability of the Thermo and Photopolymerizable Resins Used in Prosthetic Restoration after Removal of the Lower Facial Floor. Mat. Plast.,51, no. 1, 2014, p. 110

20.VITALARIU, A, TATARCIUC, M, DIACONU, D, CHECHERITA, LE. Acrylic Coustom Made Oral Appliances in Obstructive Sleep Apnea Therapy. Mat. Plast., 52, no. 2, 2015, p. 204

21.AKIN H, TUGUT F, POLAT ZA. Vitro comparison of the cytotoxicity and water sorption of two different denture base systems. J Prosthodont 2015;24:152-155.

22.ZARB GA, HOBKIRK J, ECKERT S, JACOB R. Prosthodontic Treatment for Edentulous Patients. 13th ed. Elsevier Health Sciences 2012;p.133-139.

23.VALLITTU PK, RUYTER IE, BUYKUILMAZS. Effect of polymerization temperature and time on the residual monomer content of denture base polymers. Eur J Oral Sci 1998;106(1):588-93.

24.BURAL C, AKTA a E, DENIZ G, UNLUCERCI Y, BAYRAKTAR G. Effect of leaching residual methyl methacrylate concentrations on in vitro cytotoxicity of heat polymerized denture base acrylic resin processed with different polymerization cycles. J Appl Oral Sci. 2011;19(4):30612.

25.BHOLA R, BHOLA SM, LIANG H, MISHRA B. Biocompatible denture polymers-a review. Trends Biomater Artif Organs 2010;23(3):129-36. 26.CHAVES CDAL, MACHADO AL, VERGANI CE, DE SOUZA RF, GIAMPAOLO ET. Cytotoxicity of denture base and hard chairside reline materials: a systematic review. J Prosthet Dent 2012;107(2):114-127. 27.*** International Standard ISO 20795-1 Dentistry - Base polymersPart 1: Denture base polymers 2013.

28.***AvaDent Digital Dentures; Global Dental Science LLC. Available athttp://www.avadent.com.

29.***Lab Management Today. https://Imtmag.com/articles/avadentintroduces-latest-innovations-in-digital-dentures.

30.AGUIRRE BC. Flexural Strength of Denture Base Acrylic Resins Processed by Conventional and CAD/CAM Methods. 2017. PhD Thesis. 31.GOODACRE BJ, GOODACRE CJ, BABA NZ, KATTADIYIL MT. Comparison of denture base adaptation between CAD-CAM and conventional fabrication techniques. The J Prosthet Dent 2016;116(2):249-256. 32.***http://ww w .avadent.com/wp-content/uploads/2015/09/ UofBuffalo-Study.pdf.

33.***BDLoad available at $h$ ttp://www.baltic-denture-system.de/en/lab/ bdload/

34.***Polystar product information available at http://www.merzdental.de/fileadmin/user upload/downloads/Zahntechnik/ Produktinformationen/Formenkarten/Formenk_Polystar_HK_2014.pdf 35.***Ceramil FDS available at https://www.amanngirrbäch.com/ fileadmin/_agweb_2013/media/mediathek/Print/ Catalogues_Brōochures/Brochures/EN/Ceramill_FDS_Folder_EN.pdf 36.***VITA Prosthetic Solutions available at https://www.vitazahnfabrik.com/pdb_CCFC75C700_en,,,, vmk.print

37.***https://www.3̄ders.org/articles/20150810-dentca-receives-fdaclearance-for-the-first-3d-printable-denture-base-material.html

38.HARRISON L. Three-Dimensional Printer Technology Approved for Dentures. Medscape Aug 18, 2015

39.AL-FOUZAN AF, AL-MEJ RAD LA, ALBARRAG AM. Adherence of Candida to complete denture surfaces in vitro: $A$ comparison of conventional and CAD/CAM complete dentures. Journal Adv Prosthodont 2017;9(5):402-408.

40.***IvoBase CAD available at http://www.ivoclarvivadent.ch/de-ch/ produkte/zahntechniker/ivobase-cad.

41.INFANTE L, YILMAZ B, MCGLUMPHY E, FINGER I. Fabricating complete dentures with CAD/CAM technology. J Prosthet Dent 2014;111:351-355.

42.MURAKAMI N, WAKABAYASHI N, MATSUSHIMA R, KISHIDA A, IGARASHI Y. Effect of high-pressure polymerization on mechanical properties of PMMA denture base resin. J Mech Behav Biomed Mater 2013;20:98-104.

43.RZAYEV J, PENELLE J. HP-RAFT: A free-radical polymerization technique for obtaining living polymers of ultrahigh molecular weights. Angew Chem Int Ed Engl 2004;43(13):1691-1694.

44.KWIATKOWSKI P, JURCZAK J, PIETRASIK J, JAKUBOWSKI W, MUELLER L, MATYJASZEWSKI K. High molecular weight polymethacrylates by AGET ATRP under high pressure. Macromolecules 2008;41(4):1067-1069.

45.ARITA T, KAYAMA Y, OHNO K, TSUJII Y, FUKUDA T. Highpressure atom transfer radical polymerization of methyl methacrylate for welldefi ned ultrahigh molecular-weight polymers. Polym 2008;49(10):24262429.

46.STOIA AE, TUDOR A. New Aspects of the Acrylic Teeth Denture Base Resin Bond Strength. Materiale Plastice 2016;53(1):58-60.

47.DELONG R. Global Dental Science Phase IV Report In Vitro Wear of AvaDent FM. Minnesota Dental Research Center for Biomaterials and Biomechanics. School of Dentistry. 2014.

48.WIMMER T, EICHBERGER M, LÜMKEMANN N, STAWARCZYK B. Accuracy of digitally fabricated trial dentures. J Prosthet Dent 2017 Sep 29. pii: S0022-3913(17)30485-7. doi: 10.1016/j.prosdent.2017.06.020. 49.LUNG CY, DARVELL BW. Minimization of the inevitable residual monomer in denture base acrylic. Dent Mater 2005;21(12):1119-28.

50.STEINMASSL PA, WIEDEMAIR V, HUCK C, KLAUNZER F, STEINMASSL 0 , GRUNERT I, DUMFAHRT H. Do CAD/CAM dentures really release less monomer than conventional dentures? Clin Oral Investig. 2017;21(5):1697-1705.

51.AYMAN AD. The residual monomer content and mechanical properties of CADICAM resins used in the fabrication of complete dentures as compared to heat cured resins. Electron Physician. 2017;9(7):4766-4772.

52.WIEDEMAIR V, W OLFGANG HUCK C. Monitoring water absorption of medically used PMMA using NIR. NIR news 2017;28(4):10-13.

53.ALAMMARI MR. The influence of polishing techniques on prepolymerized CADICAM acrylic resin denture bases. Electron Physician 2017;9(10):5452-5458.

54.BIDRA AS, TAYLOR TD, AGAR JR. Computer-aided technology for fabricating complete dentures: systematic review of historical background, current status, and future perspectives. J Prosthet Dent 2013;109:361-6.

Manuscript received: 15.09 .2017 